\title{
Examining change in entrepreneurial networks: \\ Using visualisation as an alternative approach
}

\begin{abstract}
Although network-based research in entrepreneurship has considered the importance of networks for small firm growth, studies have been criticised for their contradictory inferences on how entrepreneurs should embed in networks, and for overlooking the fact that networks are dynamic in nature. In this paper, we seek to contribute to entrepreneurial network literature by exploring changes in entrepreneurial networks using a network mapping approach. To meet our research objectives, we implement an innovative research design (network mapping) where entrepreneurs visually demonstrate how their networks have changed. We find that entrepreneurial networks evolve dynamically in relation to entrepreneurial stages such as opportunity exploration, initial resource gathering, incubation, early market entry, and growth. Based on the characteristics of network, the change can be defined as the initial networks change towards support-based networks, market-based networks, and the development of core networks. Given the nature of these findings, this study contributes to fostering understanding on network changes and the effectiveness of a network mapping approach as an alternative data collection methodology in network research.
\end{abstract}

\section{Keywords:}

Networks, visualisation, entrepreneurship, network mapping, network change. 


\section{Introduction}

Network research in management studies has emerged as a popular subject, especially for those seeking to understand the relationships in which individuals are embedded and how resource mobilisation through ties takes place (Koka, Madhavan, \& Prescott, 2006; Sullivan \& Ford, 2014). Over the years, entrepreneurship scholars have attempted to explain what network is and what role networks play in facilitating entrepreneurial actions. However, studies have been criticised for their contradictory inferences on how individuals should embed in networks, and for overlooking the fact that they are dynamic in nature, changing and developing over time (Slotte-Kock \& Coviello, 2010). The stage model of Larson and Starr (1993) was for many years regarded as one of the most complete theorisations on network development in the entrepreneurial context (Hoang \& Antoncic, 2003; Jack, 2010; SlotteKock \& Coviello, 2010). Yet, recent reviews of where network research is at clearly state that much more work is needed around network changes and how networks evolve in response to entrepreneurial needs (Gedajlovic, Honig, Moore, Payne, \& Wright, 2013; Hoang \& Antoncic, 2003; Jack, 2010; Jonsson, 2015; Slotte-Kock \& Coviello, 2010).

Studying networks is complex and it is a subject that is difficult to grasp, consisting of many different elements that can create data collection bias. Networks can be measured in many ways such as size, type and quality of the relationship. When used to examine the static nature of networks, the current data collection approach such as survey or interview works reasonably well. However, especially in research taking a holistic and longitudinal view of individuals' networks and their changes, this approach often has certain limitations. Studying the structure of network and how it may change overtime, researchers face considerable challenges given that how individuals develop their networks is a detailed process and that the pattern of change is not easily identifiable. The popular approach in network studies is using either traditional quantitative or qualitative data collection methods (Greve \& Salaff, 2003; Hite, 2005; Hoang \& Antoncic, 2003; MacAdam \& Marlow, 2008; Schutjens \& Stam, 2003). However, calls have been made for more innovative work focussing on these aspects, since the commonly used research methods are inadequate in solving problems of memory bias and capturing the dynamic nature of networks (Gedajlovic et al., 2013).

With the intention of filling the gap in the literature in understanding network changes in the context of entrepreneurship and the way of analysing these changes, this study aims to address two main objectives, namely, identifying the stage during new venture development where networks matter for entrepreneurship, and revealing the pattern of change in entrepreneurial networks. To address the challenge in studying network changes, this study introduces an innovative network mapping approach. Using the drawing tool, respondents were asked to visually describe their networks and tell the story behind their development. Fifteen entrepreneurs participated in the 24-month study where data were collected several times during the entrepreneurial journey. 
This study contributes to the development of new empirical evidence on change in entrepreneurial networks. In so doing, we respond to the call of scholars (e.g., Gedajlovic et al., 2013; Hoang \& Antoncic, 2003; Jack, 2010; Jonsson, 2015; Slotte-Kock \& Coviello, 2010) for a greater understanding of how networks develop over time. While previous research has asserted the importance of networks for entrepreneurship, most studies focus on networks as a means for entrepreneurship. Current studies have not analysed in details how entrepreneurs develop their networks in response to certain challenges during the entrepreneurial journey, which clearly affects the way networks should be studied in entrepreneurship. Moreover, this study contributes to understanding how data collection in network studies could be improved with a deeper insight into the development of networks through combining a traditional research method with a network mapping visualisation technique. This approach addresses the fundamental issue that many entrepreneurship and network scholars face in studying the network change phenomenon, moving beyond interviews (qualitative) and surveys (quantitative), and capturing some of the complexities, intricacies, issues, and changes that occur when entrepreneurs change their networks. Through network mapping, the data collected provide valuable visual observations of the emergence and development of networks. Taken together, the study highlights some important consideration to understand networks in the context of entrepreneurship, opening a new discussion on how networks change to meet entrepreneurial requirements.

\section{Entrepreneurial network change: Current findings and challenges}

Networks are not static but dynamic, and their content and structure can vary in response to entrepreneurial needs at a specific point in time (Burt, 1992; 2000; Hite, 2005; Ibarra, Kilduff, \& Tsai, 2005; Johannisson, 1998). In this study, we define network change as changes in networks in response to challenges and needs during a new venture's development. Reviewing the work carried out in the study of network changes, Birley (1985) explored the change in networks from informal to formal relationships, and how these change when assembling key elements for the development of new firms. Ten years later, Larson and Starr's (1993) conceptual work on the change of networks provided a model illustrating three stages of activities used to secure critical resources for entrepreneurship. These stages are: 1) focusing on essential dyadic ties, 2) converting dyadic ties to socioeconomic exchanges, and 3) layering the exchange with multiple exchange processes.

In a later study, Davidsson and Honig (2003) followed the development process of nascent entrepreneurs, identifying the links between the change in entrepreneurs' networks and the probability of market entry and success. In a similar vein, Elfring and Hulsink (2007), Gedajlovic et al. (2013), Greve and Salaff (2003), Hite (2008), Hite and Hesterly (2001), Jack (2005), and Schutjens and Stam (2003) presented the role of networks and how the dynamic nature of networks can affect a venture's evolution, growth, and development. While overall the studies on network change commonly support the important role of networks for entrepreneurship, current understanding of how networks change 
over time is still inconclusive. Scholars have developed different empirical models in understanding the factors that influence change. Nonetheless, how networks change in their characteristics and the relationship with their entrepreneurial context has not been clearly explored. Table 1 summarises some of the key findings from where the large variety of approaches and perspectives that have been used in understanding network change can be recognised. 
Table 1

Some important studies on network change.

\begin{tabular}{|c|c|c|}
\hline Authors & Findings related to network change & $\begin{array}{l}\text { Findings related to the methods and the } \\
\text { network characteristics }\end{array}$ \\
\hline Larson, 1992 & $\begin{array}{l}\text { The study proposes a process model of the formation of entrepreneurial dyads, including preconditions, } \\
\text { conditions to build the exchange structures, and the final phase of integration and control. }\end{array}$ & $\begin{array}{l}\text { An ethnographic study focusing on } \\
\text { networks in general. While the study } \\
\text { mainly considers the relational dimension, } \\
\text { early findings on the structural dimension } \\
\text { of networks are also presented. }\end{array}$ \\
\hline $\begin{array}{l}\text { Larson \& Starr, } \\
1993\end{array}$ & $\begin{array}{l}\text { Building on theories of social and socio-economic exchange, the study developed a model explaining the } \\
\text { transformation of exchange relationships from a set of relatively simple into dense, multidimensional } \\
\text { and multi-layered inter-organisational exchange relationships. }\end{array}$ & $\begin{array}{l}\text { A conceptual paper focusing on dyadic } \\
\text { ties. }\end{array}$ \\
\hline $\begin{array}{l}\text { Hite \& Hesterly, } \\
2001\end{array}$ & $\begin{array}{l}\text { This study addresses whether cohesive networks of socially embedded ties or sparse networks rich in } \\
\text { structural holes are more conducive to the success of new firms. The study finds that networks evolve } \\
\text { towards more ties based on a calculation of economic costs, while both cohesive and sparse networks are } \\
\text { conducive to firm performance. }\end{array}$ & $\begin{array}{l}\text { A conceptual paper focusing on the } \\
\text { relational dimension (embeddedness) and } \\
\text { structural dimension (structural holes) in } \\
\text { the context of the early growth of firms. }\end{array}$ \\
\hline $\begin{array}{l}\text { Schutjens \& } \\
\text { Stam, } 2003\end{array}$ & $\begin{array}{l}\text { This paper describes the evolution of networks in the first three years after start-up and puts forward } \\
\text { explanations of the nature of networks of young firms after three years. The study finds that business } \\
\text { relationships become increasingly social and influenced by a geographic concentration strategy. }\end{array}$ & $\begin{array}{l}\text { A quantitative study focusing on business } \\
\text { networks in general. The study considers } \\
\text { size and location as determinant factors. }\end{array}$ \\
\hline $\begin{array}{l}\text { Lechner \& } \\
\text { Dowling, } 2003\end{array}$ & $\begin{array}{l}\text { The paper focuses on high-growth entrepreneurial firms in the IT industry, exploring how these firms } \\
\text { grow through external relations and become competitive. The study finds that the relational mix changes } \\
\text { with the development of firms. }\end{array}$ & $\begin{array}{l}\text { A qualitative study using an egocentric } \\
\text { approach and looking at networks from a } \\
\text { multi-dimensional perspective (relational } \\
\text { mixed). }\end{array}$ \\
\hline $\begin{array}{l}\text { Lechner, } \\
\text { Dowling, \& } \\
\text { Welpe, } 2006\end{array}$ & $\begin{array}{l}\text { This study examines the role of different networks, called the relational mix, on the development of the } \\
\text { entrepreneurial firm. The results suggest that different types of networks are important for firm } \\
\text { development. }\end{array}$ & $\begin{array}{l}\text { A quantitative study focusing on the } \\
\text { nature/type of networks. }\end{array}$ \\
\hline Hite, 2005 & $\begin{array}{l}\text { Using qualitative case study methods, the study focuses on relational ties and suggests that evolutionary } \\
\text { processes where ties enter the network through personal relationship evolve more quickly towards full } \\
\text { embeddedness. }\end{array}$ & $\begin{array}{l}\text { Mixed method combining interviews and a } \\
\text { longitudinal study. }\end{array}$ \\
\hline $\begin{array}{l}\text { Koka, } \\
\text { Madhavan, \& } \\
\text { Prescott, } 2006\end{array}$ & $\begin{array}{l}\text { The study develops a framework examining the relationship between environmental change and patterns } \\
\text { of network change. The proposed patterns show some indication of changes in the structural and } \\
\text { relational characteristics. }\end{array}$ & $\begin{array}{l}\text { A conceptual study examining networks in } \\
\text { general. }\end{array}$ \\
\hline $\begin{array}{l}\text { Jack, Dodd, \& } \\
\text { Anderson, } 2008\end{array}$ & $\begin{array}{l}\text { The study presents an extensive empirical investigation of network change from three longitudinal case } \\
\text { studies. Focusing on the relational characteristic, the study provides chronological patterns of network } \\
\text { continuity and change. }\end{array}$ & $\begin{array}{l}\text { An ethnographic study focusing on the } \\
\text { nature of networks and the change of } \\
\text { networks. }\end{array}$ \\
\hline
\end{tabular}




\begin{tabular}{|c|c|c|}
\hline $\begin{array}{l}\text { Jack, Moult, } \\
\text { Anderson, \& } \\
\text { Dodd, } 2010\end{array}$ & $\begin{array}{l}\text { Using a qualitative approach over a six-year period, the study identifies network changes and provides } \\
\text { information on the structural characteristics of network dynamics. Findings show that the network } \\
\text { structure shifts from calculative to affective ties, and demonstrates the importance of social ties for } \\
\text { network change. }\end{array}$ & $\begin{array}{l}\text { An ethnographic study focusing on the } \\
\text { relational characteristics of networks. }\end{array}$ \\
\hline $\begin{array}{l}\text { Slotte-Kock, \& } \\
\text { Coviello, } 2010\end{array}$ & $\begin{array}{l}\text { The study reviews entrepreneurship literature on networks and develops the concept of process to the } \\
\text { study of networks. }\end{array}$ & A conceptual paper on networks. \\
\hline $\begin{array}{l}\text { Kreiser, Patel, } \\
\& \text { Fiet, } 2013\end{array}$ & $\begin{array}{l}\text { This study examines how founders can manage changes in their network ties during firm founding. The } \\
\text { study finds that an increase in tie strength is negatively associated with founding activities, whereas an } \\
\text { increase in the number of ties is positively associated with founding activities. }\end{array}$ & $\begin{array}{l}\text { A quantitative study focusing on the } \\
\text { structural dimension of networks. }\end{array}$ \\
\hline $\begin{array}{l}\text { Newbert, } \\
\text { Tornikoski, \& } \\
\text { Quigley, 2013 }\end{array}$ & $\begin{array}{l}\text { The study shows that the more heterogeneous the strength of a nascent entrepreneur's network, the more } \\
\text { likely the emergence of his/her organisation. }\end{array}$ & $\begin{array}{l}\text { A quantitative study focusing on the } \\
\text { relational dimension of networks. }\end{array}$ \\
\hline $\begin{array}{l}\text { Sullivan \& } \\
\text { Ford, } 2014\end{array}$ & $\begin{array}{l}\text { The study investigates how entrepreneurs may use networks to address changing resource needs during } \\
\text { early venture development. Results show that the structural characteristics of the entrepreneurs' } \\
\text { networks at venture launch are associated with network structure and content in early venture } \\
\text { development in ways that may promote access to resources. }\end{array}$ & $\begin{array}{l}\text { A quantitative study focusing on the size } \\
\text { and the relational dimension of networks. }\end{array}$ \\
\hline $\begin{array}{l}\text { Engel, } \\
\text { Kaandorp, \& } \\
\text { Elfring, } 2017\end{array}$ & $\begin{array}{l}\text { The study attempts to theorise how entrepreneurs act when desired ties cannot be identified in advance, } \\
\text { networking outcomes cannot be predicted, and ongoing social interactions foster the emergence of new } \\
\text { objectives. }\end{array}$ & $\begin{array}{l}\text { A conceptual paper discussing how } \\
\text { entrepreneurs maintain and develop } \\
\text { networks. }\end{array}$ \\
\hline
\end{tabular}


Overall, the above table highlights some conceptual understanding and empirical evidence on how networks change using both quantitative and qualitative approaches. However, scholars argue that more work that specifically deals with this is needed, since existing studies still lack clarity and overlook the network development process (Hite, 2005; Hite \& Hesterly, 2001; Hoang \& Antoncic, 2003; Lechner \& Dowling, 2003; MacAdam \& Marlow, 2008; Martinez \& Aldrich, 2011; Slotte-Kock \& Coviello, 2010; $)^{1}$. In their work, Slotte-Kock and Coviello (2010) identify specific questions that they deem key to developing knowledge and understanding on network changes. More specifically, these questions relate to which changes, how, and why networks change. They argue that while these questions offer an integrated overview of the way in which network development might be understood, answering them all in a single research study would be a tremendous challenge, if not impossible (Slotte-Kock \& Coviello, 2010). Other network scholars (Gedajlovic et al., 2013; Jack et al., 2008; Jonsson, 2015; Parkhe, Wasserman, \& Ralston, 2006) also reflect on this need, arguing that looking at how and why networks change will help develop further understanding.

\section{Alternative approach to studying network change}

As Table 1 shows, studies on network change use both a qualitative and quantitative approach. In relation to the qualitative approach, previous studies have developed a conceptual understanding of network change, studying the strength level of dyadic ties and the role of factors in influencing the development of ties. While these studies offer explanations on the development process, they neglect portraying ties as part of a complex entrepreneurial ecosystem, dynamically adapting to the context and the challenges faced by entrepreneurs. In this case, both strong and weak ties have positive impact depending on the needs during the entrepreneurial journey. Using the latter approach, studies have attempted to examine the pattern of changes by focusing on the structural characteristics of networks. However, the findings are inconclusive on the direction of network changes and the structure of networks. For instance, entrepreneurs may benefit from developing either network with structural holes or dense network during the development of a new business.

To benefit from both approaches, this study aims to examine the development of networks using both a qualitative and quantitative approach. Given that in small entrepreneurial firms innovation activities tend to be dominated by, and depend on, the entrepreneur's competencies, this study considers personal, not firm, networks (Johannisson, 1998). Since our interest is in determining participants' own understanding and their personal experiences (Leitch, Hill, \& Harrison, 2010), we adopt an interpretivist position. The interpretative approach may lead to a more in-depth understanding and is relevant when looking to further develop and generate network theory (Hite, 2008; Hoang \& Antoncic, 2003;

\footnotetext{
${ }^{1}$ Jack et al. (2008) summarise the majority of work thus far undertaken and, like others, show that with the exception of Larson and Starr (1993), there is limited work on which to base future studies.
} 
Krackhardt, 1995). We hence draw on qualitative techniques to explore our area of interest. However, we chose to use not only traditional qualitative techniques, such as interviews, but also adopted an approach that might help overcome certain obstacles, such as memory issues and participants being too immersed in their current situations, which could lead to some bias. Our approach allowed participants to thoroughly express their experiences and reflect on how their networks had changed. To help respondents focus on their networks, we constructed a physical model in the form of a network map (von der Lippe \& Gamper, 2016). Participants were asked to imagine, visualise, and later describe their networks using drawing as a tool. As a result, the visual object deriving from this activity can be regarded as a refined reflection of the participants' networking activities. Overall, the use of physical models in explaining strategy is not new (Ansoff, 1965; Huff, 1990; Huff \& Jenkins, 2002; Mintzberg, 1987; Porter, 1980). Mintzberg (1987) used a similar approach when discussing the metaphor of the potter working the clay as an illustration of the strategy-making task and process as hands-on craftsmanship. Piaget (1971) argued that abstract concepts are not necessarily innate categories as philosophers have proposed. Instead, understanding seems to grow from the feedback processes between the living mind and the encompassing world. In addition, the visual data can also be examined quantitatively. The network maps provide information to measure the characteristics of the entrepreneurs' network, such as strength of ties and network density.

\subsection{Study sample}

In this study, we used purposeful sampling to identify participants (Hoepfl, 1997). We first identified a set of entrepreneurs that could potentially be included in the study through preliminary interviews with academic staff, the managers of incubators, and officers from the university knowledge exchange/transfer units who provided a preliminary list and references of more than 60 entrepreneurs. After establishing contact with the entrepreneurs/owner managers and conducting a preliminary interview, almost half the initial sample (35 entrepreneurs) met the following three conditions: (1) established less than 5 years ago; (2) in the process of starting a business, penetrating a market, or growing the initial market. More specifically, this study aimed to select entrepreneurs who were starting to commercialise their business ideas at the beginning of the study; (3) agreed to be visited several times over the 24-month period. Unfortunately, only 15 entrepreneurs participated until the end of the study.

The entrepreneurs included in the final sample were from the northwest the United Kingdom (UK) and were equally distributed between product (54\%) and services (46\%), as well as between businessto-business (60\%) and business-to-consumer industries (40\%). With regards to the sector, the sample are varied covering manufacturing, information technology, chemical, biotechnology and material science, medical, construction and transportation. The firms' size ranged from 1 and 15 employees with an average of 7. At the time of data collection, the firms' age ranged from 1 to 3 years with an average of 1.35 . The sample was clustered into 3 groups of entrepreneurs. The first group consisted of 5 
entrepreneurs in the very early stage of idea generation without any formal form of organisation. The second group included 7 entrepreneurs in the early stage of developing their products/services. The last group consisted of 3 entrepreneurs who had recently started market penetration. The sample from different stages of venture development enabled a sufficiently large and diverse sample to examine network changes in the context of entrepreneurship.

\subsection{Data collection}

Data collection was undertaken in two sessions. In the first session, we ran the introduction workshop followed by a series of individual sessions over a period of 24 months. To start the study, we designed a half-day interactive workshop inviting all respondents to visually show their networks and how these evolved in certain contexts and in their experiences (Bürgi, Jacobs, \& Roos, 2005). The steps in the workshop are described as follows:

In Step 1, the respondents were asked to generate the names of their network contacts using the egocentric approach or name generator technique (Burt, 1992). However, the name generation at this stage was not static, since the respondents could add contact names during the remaining activities. The workshop was intended to be interactive, so rather than just generating names, respondents were encouraged to visualise their own networks and at the same time reflect on the nature of their networks through discussions and written notes. Another advantage of this method is not setting a limit to the number of contacts participants could refer to, although for ease of analysis, we aimed for a maximum 12 ties. In asking participants to identify the most important contacts during the development of their firms, many studies report setting a limit of 4 to 6 contacts (McEvily \& Zaheer, 1999). However, this approach may force respondents to include only the most important or current contacts. In this step, respondents were also invited to note down some characteristics of their network contacts.

In Step 2, the respondents were asked to draw a map of their existing networks. We also requested an additional map from respondents who had started the commercialisation process more than a year previously. Our intention was to capture the networks in the early stage and potentially provide more information on network changes.

In Step 3, respondents were asked to reflect on the role of their network contacts. This step also sought to increase the validity of this approach by encouraging participants to re-think the role of their networks. To generate data and maintain the research focus, we undertook participant observation alongside a semi-structured discussion guide that formed the basis for analysis (Bürgi et al., 2005), exploring the themes through visualisations, discussions, and storytelling. They included, for example, information about specific individuals, the help and support of individuals, the nature of this help and support, how and for how long they had known the individuals, their background, the impact of the help received, the change that was brought about, the impact of such change on both the entrepreneurial activity and the network. In addition, we investigated how respondents interacted with their contacts 
and the way they were invited to the networks. As a result, the stories emerged of when participants interacted with each network contact in a certain entrepreneurial context.

After the workshop, we conducted individual sessions. We visited each respondent at least once in six months, and in each session, asked participants to reflect on their critical moments in this six-month period (Chell, 1998), which could represent the best or worst experience in their entrepreneurial journey. The focus of this activity was self-defined criticality, inasmuch as it was their personal interpretation of the salient moments of prime importance to their businesses. We carefully separated the concept of criticality from the more popular notion of crisis, which is typically perceived as a negative term. Although crisis may serve as a catalyst for network change, the moments or experiences perceived as positive are deemed just as important as those that are problematic. For instance, the entrepreneurs met a venture capitalist or won a business plan competition that allowed materialising their business concept. This approach also provides a better understanding of the world participants live in and the context in which they operate (Hoepfl, 1997; Patton, 1990). The discussion during the individual sessions aimed to help respondents compare and contrast situations and experiences. The conversations were informal, questions and areas of investigation were not addressed in any specific order, but governed by their actual situations (Gummesson, 2000). Throughout the data collection process, we used probes (Easterby-Smith, Thorpe, \& Lowe, 2002) to ensure the interviewer was not led in any way, helping to confirm that the details received from respondents reflected the actual situations and experiences encountered (Jack, 2005). The overall sessions lasted between 45 to 60 minutes.

In terms of data collected, the process led to the following:

At least six to eight network maps for each respondent, which provided a visual representation of the network change for each participant.

- $\quad$ A story of each participant's entrepreneurial journey.

\subsection{Data analysis: Qualitative and quantitative approaches to study network change}

We analysed and interpreted the data using a qualitative and quantitative approach (Bryman \& Bell, 2003). In the first approach, our objective was to examine the role of networks in supporting entrepreneurship activities to identify the reason and context behind the network change. To organise, categorise, and analyse the data, we followed the framework of Eisenhardt (1989), and Bogdan and Biklen (1982). The first step consisted in creating provisional categories and first-order codes. We began by identifying statements in the interview scripts via open coding, thereafter drawing on common statements, comparable episodes, and equivalent content in the archival data to form provisional categories and the first-order codes. The second step consisted in integrating the first-order codes and creating second-order themes. The codes were consolidated for each group. This stage of analysis aimed to compare the context and changes of the variable of interest, namely, the entrepreneurs' network. As the categories became consolidated, we used axial coding to observe the network change mechanism 
and context. The third step involved delimiting the theory by aggregating the theoretical dimensions. However, this process was not linear, but iterative whereby the researcher moved back and forth between the data and an emerging structure of theoretical arguments that responded to the theory questions presented above. This meant sifting and searching through the interview data and notes taken from the observations around the study themes: networks, network change, and entrepreneurship. This also consisted in searching data for the network map. In essence, this took the form of looking at the data and asking "what is going on here?", an accepted approach in network analysis in the entrepreneurial context (Hill, McGowan, \& Drummond 1999).

The quantitative analysis of the study aimed to identify the network change pattern. To understand the network change, we examined both the relational and structural dimensions of the networks. The relational dimension refers to the quality of relationships between individuals and their contacts. Although some scholars (Aldrich, Rosen, \& Woodward, 1987; Coleman, 1990; Hill et al., 1999; Granovetter, 1982; Jonsson, 2015; Podolny \& Baron, 1997) argue that the relational dimension is more beneficial for supporting growth, they differ on whether strong or weak relationships are important. For example, Brüderl and Preisendörfer (1998) and Jack (2005) argue that strong ties are more prevalent as they facilitate trust, commitment, transferring tacit knowledge, and the willingness of actors to support each other reciprocally. In contrast, Granovetter (2005) argues that new information is obtained through weak ties rather than strong ties, positing that since strongly connected actors are likely to interact frequently, much of the information that circulates in the social system is redundant. Entrepreneurs can gain new perspectives and insights through communicating and exchanging ideas with people they do not meet very often, namely, via weak ties. Therefore, weak ties also provide access to a wider array of people and more non-redundant information (Burt, 1992, 2000). According to Granovetter (1982), the relational dimension is a linear combination of the amount of time, the emotional intensity, the intimacy, and the reciprocal service that characterises the tie.

In this study, we constructed the relational dimension as a composite variable derived from three rank variables: frequency of face-to-face interaction $(i)$, duration of relationship $(d)$, and entrepreneurs' assessment of closeness of the relationship $(c)$ with partners $(n)$ (Burt, 1992). A high value indicates a relatively strong tie $(\min 0, \max 1)$. The formula is as follows:

$$
\left(\frac{\sum_{p=1}^{n} i_{p}+\sum_{p=1}^{n} d_{p}+\sum_{p=1}^{n} c_{p}}{3 n}\right) / 3
$$

The structural characteristic of networks refers to the composition and structure of the network (Baum, Calabrese, \& Silverman, 2000; Burt 2005; Martinez \& Aldrich, 2011). In a high-density network, individuals are connected, meaning they know each other. In contrast, a low-density network is characterised by individuals that are strangers to each other. Coleman (1990) suggests a high-density network can reduce the risks of uncertainty, and create trust and efficiency when transferring 
information and knowledge. In a high-density network, information known to one person is rapidly diffused to others and interpreted in similar ways (Granovetter, 2005). Moreover, high-density networks may improve the communication of tacit knowledge (Hansen, 1999). In contrast, a low-density network with structural holes enables the discovery of opportunities due to the bridge to new and different information (Ibarra et al., 2005; McEvily \& Zaheer, 1999). Structural holes separate non-redundant sources of information that benefits individuals, as they have more control and rewarding opportunities (Burt, 2000). Individuals that bridge structural holes are said to be well-positioned to efficiently and quickly learn and develop novel responses to trends, enhance efficiency, have better access to resources (including information or knowledge), with better identification and responses to emerging threats and opportunities (Zaheer \& Bell, 2005). For the structural dimension, we observed the level of network density. The variable was measured as the number of links that exist in a network ( $t$ ) divided by the maximum possible number of links that could exist in the network (Borgatti et al., 1998). A high value indicates a relatively dense network $(\min 0, \max 1)$. The formula is as follows:

$$
2 t /(n(n-1))
$$

where $n$ is the total number of contacts.

In addition to the structural and relational dimension of networks, we also considered their size. Entrepreneurs may actively engage in networking activities that result in an increase in network contacts. The bigger the network size, the more opportunities for entrepreneurs to access resources. However, networking is not without limitations or the limited capacity of entrepreneurs to develop and maintain networks. As a result, we examined the change in network size to understand how entrepreneurs change their networks.

\section{Empirical findings}

\subsection{The role of networks in entrepreneurial stages of new venture development}

In this section, we discuss the role of networks in the context of entrepreneurship. Overall, the data suggests that the entrepreneurs change networks over five distinct entrepreneurial stages, where each stage required the entrepreneurs to seek support from their networks. Table 2 illustrates the process of identifying the stages and the needs that trigger the change in entrepreneurial networks.

Table 2 Overview of data structure and the emerging theme of context.

\begin{tabular}{|l|l|l|l|}
\hline First-order codes & Examples of quotes & $\begin{array}{l}\text { Second-order } \\
\text { themes }\end{array}$ & $\begin{array}{l}\text { Third-order } \\
\text { aggregate } \\
\text { concept }\end{array}$ \\
\hline $\begin{array}{l}\text { Entrepreneurs refer to their } \\
\text { first 'eureka moment' and } \\
\text { how networks define their } \\
\text { subsequent entrepreneurial } \\
\text { actions }\end{array}$ & $\begin{array}{l}\text { "It was my professor that told me } \\
\text { about making money from this } \\
\text { technology" }\end{array}$ & $\begin{array}{l}\text { Ideas } \\
\text { exploration }\end{array}$ & exploration \\
\hline
\end{tabular}




\begin{tabular}{|c|c|c|c|}
\hline $\begin{array}{l}\text { Entrepreneurs' episodes in } \\
\text { discussing ideas with their } \\
\text { family }\end{array}$ & $\begin{array}{l}\text { "I was not sure whether I could make } \\
\text { a living from it. My family came to } \\
\text { help me, especially my wife" }\end{array}$ & Confirmation & \\
\hline $\begin{array}{l}\text { Entrepreneurs' episodes } \\
\text { putting forward their request } \\
\text { for supports }\end{array}$ & $\begin{array}{l}\text { "I didn't have any problem when I told } \\
\text { my boss that I was leaving. My } \\
\text { decision was mainly supported by him } \\
\text { and he continued to give me advice" }\end{array}$ & Seeking support & \multirow[t]{2}{*}{$\begin{array}{l}\text { Initial resource } \\
\text { gathering }\end{array}$} \\
\hline $\begin{array}{l}\text { Entrepreneurs describe the } \\
\text { role of close networks in } \\
\text { providing initial resources }\end{array}$ & $\begin{array}{l}\text { "I started with trust from my family. } \\
\text { My dad was my first investor; I } \\
\text { borrowed money from him to start" }\end{array}$ & $\begin{array}{l}\text { Acquiring initial } \\
\text { resource }\end{array}$ & \\
\hline $\begin{array}{l}\text { Entrepreneurs discuss the role } \\
\text { of networks in solving } \\
\text { obstacles during } \\
\text { product/service development }\end{array}$ & $\begin{array}{l}\text { "His role is immense for me. I always } \\
\text { go to him at least once a week. He } \\
\text { helps me with the design" }\end{array}$ & $\begin{array}{l}\text { Product } \\
\text { development }\end{array}$ & \multirow[t]{2}{*}{ Incubation } \\
\hline $\begin{array}{l}\text { Entrepreneurs' episodes } \\
\text { solving problem related to the } \\
\text { start-up process }\end{array}$ & $\begin{array}{l}\text { "He started the business earlier than } \\
\text { me. Although he is younger than me, } \\
\text { his success shows how good he is. I } \\
\text { have learnt a lot from him in the last } \\
\text { six months" }\end{array}$ & Learning & \\
\hline $\begin{array}{l}\text { Entrepreneurs' episodes } \\
\text { regarding first buyer } \\
\text { engagement and the role of } \\
\text { networks }\end{array}$ & $\begin{array}{l}\text { "I have failed many times, until I hit } \\
\text { this. Credit to her. I was able to } \\
\text { convince them because of her" }\end{array}$ & $\begin{array}{l}\text { Market } \\
\text { penetration }\end{array}$ & \multirow[t]{2}{*}{$\begin{array}{l}\text { Early market } \\
\text { entry }\end{array}$} \\
\hline $\begin{array}{l}\text { Entrepreneurs describe the } \\
\text { process of entering a market } \\
\text { for the first time and how } \\
\text { networks provide access and } \\
\text { supports. }\end{array}$ & $\begin{array}{l}\text { "The reason for having him on-board } \\
\text { is because we need a strong and } \\
\text { reputable partner who understands the } \\
\text { market" }\end{array}$ & Partnership & \\
\hline $\begin{array}{l}\text { Entrepreneurs referring to } \\
\text { strategy for new markets and } \\
\text { use the network to facilitate } \\
\text { the process }\end{array}$ & $\begin{array}{l}\text { "I have known him since we were } \\
\text { kids. He is my consultant, mentor, and } \\
\text { friend. At the moment, we are } \\
\text { discussing another opportunity for } \\
\text { North America" }\end{array}$ & $\begin{array}{l}\text { Market } \\
\text { expansion }\end{array}$ & \multirow[t]{2}{*}{ Growth } \\
\hline $\begin{array}{l}\text { Entrepreneurs' episodes in } \\
\text { expanding the business by } \\
\text { involving the network }\end{array}$ & $\begin{array}{l}\text { "I put him in charge of my business. } \\
\text { He is better at growing the business. } \\
\text { For me, managing the business is a bit } \\
\text { boring, but I'll start a new project" }\end{array}$ & Exit & \\
\hline
\end{tabular}

\subsubsection{Opportunity framing}

The first indication of the role of networks in entrepreneurship emerged when the ideas or opportunities were presented to the entrepreneurs. In this stage, they assessed the potential commercialisation and measured the risk of starting a business. Using network-mapping activities and interviews, the study reveals that the entrepreneurs relied on their networks to examine whether the opportunity had sufficient value for further exploitation. The study found that the entrepreneurs use family, friends and colleagues to examine the value of opportunity, as one of the respondents expressed: "Friends tell the truth. They tell you if they don't like it. If I can't convince my own friend, how can I sell my service? I don't want to talk to consultants or people whose business is to make money by supporting start-ups. I need them later, but not now" (John-interview 008). Moreover, some occasions showed that the opportunity could also be derived from networks. For instance, Rick did not realise the commercial potential of his research until a student wrote a business plan for him as part of a course assignment. As Rick stated: “... when you're working on your research, the mentality is too push the 
scientific discovery. I barely see any opportunity. I was not interested in making money. Until I met Ton. During my time in supervising him, he told me that he could sell my research. I thought he was joking but he had made me consider to commercialise my research.” (Rick-interview 013)

\subsubsection{Initial resource gathering}

The next stage where entrepreneurs reached out to their network contacts was when they were in the process of making the decision to commit to an entrepreneurial journey. This stage is critical in the start-up process, as entrepreneurs need to make a commitment in terms of their personal career and life. Our study found that networks helped the entrepreneurs gather initial resources and provide psychological support. Reflecting on his early network, Mike mentioned that his networking activity in this stage was mainly about trying to gather resources such as market information, initial investment and potential barriers: "It was my brother who was the first to help me ... He was a true supporter. He informed me about what is possible and what is not possible ... he works in a big consultancy and I really benefitted from his insights and supports, but most important, he gave me access to his networks." (Mike - interview no 031). The data also provides evidence on the role of networks in helping entrepreneurs overcome their doubts. "I benefited from his guidance. I was not ready to quit my old job and almost gave up. But he mentored me and I shadowed him for months. I gained not only valuable knowledge but also confidence and understood the consequence of an entrepreneur's life. The process has helped me make the right decision" (Jon - interview 039). Overall, the study found that communicating with the network provides entrepreneurs with initial resources that helps them move forward.

\subsubsection{Incubation}

Having framed the opportunity and committed to commercial exploitation, entrepreneurs started developing their product or service. The data suggests that they relied on networks especially as a means of acquiring resources for product development (prototyping), as one of the entrepreneurs expressed: "If it were not for him, I wouldn't be able to stand here and tell you my story. He helped me with the first investment, mentored me ... but the most important thing was to open the door to his incubator facility "(Lin-interview 65). In half the cases, evidence emerged that the entrepreneurs sought help from external organisations, such as incubators, universities, consultants, and other intermediary organisations. Through their contacts on those organisations, entrepreneurs are exposed to new knowledge and information that allows them to experience the steepest learning curve, especially for those with little or no business knowledge and experience. "Starting a business is like learning by doing, making mistakes along the way. I was lucky to know him as a mentor. He is a true believer in my idea. He has guided me to find the right strategy, but has also encouraged and challenged me to bring the company to this state" (Tom - interview 45). For some of the entrepreneurs in our study, incubators 
have provided a good environment for learning. By observing other entrepreneurs in the networks, Olga learnt to correct her mistakes and improve her business strategy. "Before, I was so excited about the prospect. I tried to look from a different angle, everything looked promising. But I was wrong; my initial plan did not work. I then learned from other start-ups here. They became part of my network. We are helping each other. They have gone through the same journey" (Olga-interview 092).

\subsubsection{Early market entry}

Once the entrepreneurs gained sufficient credibility to access and acquire resources to start-up the business, they attempted to generate early returns by testing the market. In this context, the role of networks significantly intensified. Entrepreneurs use networks to continuously identify, acquire, and integrate resources, subsequently re-configuring them (Galunic \& Eisenhardt, 2001). From the interviews, it became apparent that for most of the entrepreneurs, the initial idea or opportunity was imprecisely defined, ambiguously targeted, and far from practical. In some cases, the findings show that there was a lack of clarity over a suitable market, how the product would perform commercially, and what channels could be used to exploit the opportunity in the market. Our finding shows that all difficulties in entering market has forced entrepreneurs to seek supports from their network. For example, Tom struggled to find a suitable market for his invention. Although he developed a product with a novel technology, he faced uncertainty over market acceptance, as he stated: "My main issue here is to find a market entry. Overall, I am struggling to overcome the entry barrier and developing a new commercially feasible product seems to be impossible. Unfortunately, the support is not adequate and it has forced me to actively engage with them (he referred to a consultant funded by regional development funds)" (Tom - interview 145). In a similar scenario, Lin decided to readjust her business after having spent a year trying to develop a measurement device based on their technology. She recognised that she was wasting her resources on a market that was too small, and more importantly, was marketing the technology in the wrong way. "We failed to get our product to market the first time around, but in the process, we understood just how much we need someone to open the door. We underestimated the market. If I had known this, I would have found better support" (Lin - interview 108). In the end, she found a new business partner from her networks, and together they expanded the business into a new overseas market.

\subsubsection{Market growth}

The final stage where networks again play a significant role is during the market growth stage. In this stage, entrepreneurs have successfully entered the market. While there were signs of a steady and promising income stream, the entrepreneurs started to consider the future growth of their business. Again, the study witnessed the emergence of the new role of networks in this context, as the current networks had limited capacity in supporting the entrepreneurs with their new challenge in the growth 
stage. This challenge to sustain business growth forced the entrepreneurs to turn into their networks, as in John's case. The company has grown rapidly in just three years, but John knew that he needed an experienced business partner: "We reached critical mass a month ago and we've grown the company by $150 \%$ in the last financial year. We are now targeting 5 million a year turnover. I am aiming to grow to 50 to 60 staff. I know this is a very ambitious plan, and therefore we invited him to join our board of directors. This is a game changer for our business" (John - interview 186). Another example is Evan's case. Although he was able to commercialise the product, the market was too small. Evan realised that he needed to look for an international market. While the existing networks did not provide Evan with access to information or resources on internationalisation, he used his connection with the university to find solution. "I benefited from European funding for SMEs. It opened a new opportunity for me. As you can see, my networks have changed. The funding provides me with the access to mentoring, and more importantly, direct access to the Chinese market. Next week I will meet a new business partner in China" (Evan - interview 150). In both cases, the entrepreneurs rely on their network to grow the business further.

\subsection{The network change process}

While the previous section shows the stage during new venture development where entrepreneurs seek help from their networks, the following section focuses on how the entrepreneurs changed their networks. Using network maps produced by the respondents, the pattern of network change can be identified. To measure the change, Table 3 provides the statistical analysis of three network characteristics, namely, strength of ties, network density, and network size. The first significant change in terms of the strength of ties occurred between the initial resource gathering and incubation stages. The number of strong ties decreased as new ties were introduced to the networks. This trend continued further until the early market entry. Over time, the new ties became stronger as the entrepreneurs moved from the early market entry to the market growth stage. Similarly, the addition of new ties in the incubation stage reduced the level of network density. Networks were more open with an addition of new ties creating structural holes in the incubation stage. The study found that the entrepreneurs maintain the trend of having a low-density network until the final stage. With regard to network size, the study found that the entrepreneurs started with a few network contacts. The number significantly increased in the incubation stage. In the next stage, some new ties were added while old ties disappeared. Finally, the number of contacts decreased in the last stage. 
Table 3 The change of networks (Paired sample t-test)

\begin{tabular}{|c|c|c|c|c|c|}
\hline 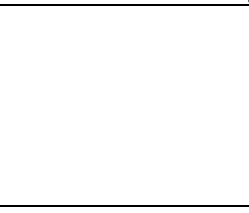 & $\begin{array}{l}\text { Opportunity } \\
\text { exploration } \\
\text { (1) }\end{array}$ & $\begin{array}{l}\text { Initial } \\
\text { resource } \\
\text { gathering } \\
(2) \\
\end{array}$ & $\begin{array}{l}\text { Incubation } \\
\text { (3) }\end{array}$ & $\begin{array}{l}\begin{array}{l}\text { Early market } \\
\text { entry }\end{array} \\
\text { (4) }\end{array}$ & $\begin{array}{l}\text { Market } \\
\text { growth } \\
\text { (5) }\end{array}$ \\
\hline \multirow[t]{3}{*}{ Strength of ties } & $0.67(0.15)$ & $0.65(0.20)$ & $0.45(0.27)$ & $0.20(0.16)$ & $0.48(0.30)$ \\
\hline & & T-test (1 and 2) & T-test (2 and 3) & T-test (3 and 4) & T-test (4 and 5) \\
\hline & & 1.02 & $3.87 *$ & $4.07 * *$ & $4.34 * *$ \\
\hline \multirow[t]{3}{*}{ Network density } & $0.48(0.31)$ & $0.45(0.27)$ & $0.26(0.15)$ & $0.28(0.20)$ & $0.32(0.28)$ \\
\hline & & T-test (1 and 2) & T-test (2 and 3) & T-test (3 and 4) & T-test (4 and 5) \\
\hline & & 1.26 & $4.93 * *$ & 2.17 & 2.97 \\
\hline \multirow[t]{3}{*}{ Size of network } & $3.44(0.98)$ & $4.01(2.04)$ & $6.65(1.98)$ & $6.29(2.87)$ & $4.06(0.87)$ \\
\hline & & T-test (1 and 2) & T-test (2 and 3) & T-test (3 and 4) & T-test (4 and 5) \\
\hline & & 2.90 & $4.67 * *$ & 1.65 & $5.06 * *$ \\
\hline
\end{tabular}

Note: The above value represent: mean (SD); $*: p<.05 ; * *: p<.01$

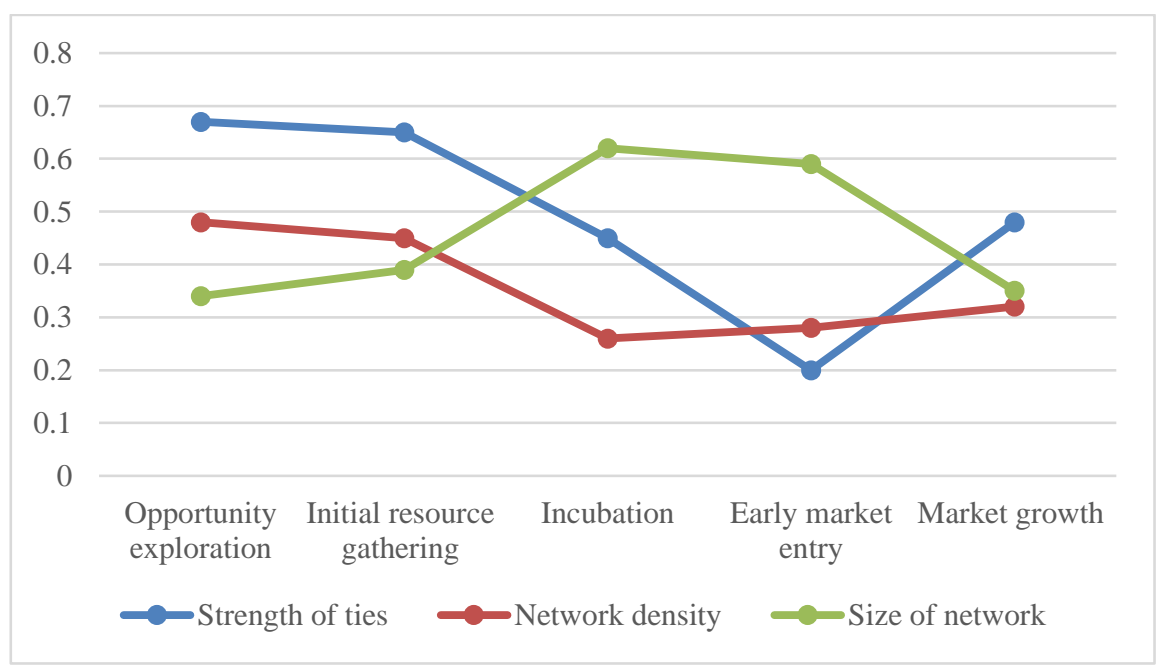

Note: the value of variable size of network was standardised by dividing each average size by the overall maximum size.

Fig. 1. The network change pattern.

\subsubsection{The first change in entrepreneurial networks: The creation of initial networks}

The study suggests that the earliest networking activities start with connecting and reconnecting with old contacts. The network visualisation shows that in the early stage, the networks are seen as cohesive, family- and friends-based, consisting of many strong ties. This confirms Hite's (2005) finding on the presence of identity-based ties in the very early stage. Identity-based ties are defined as egocentric networks that have a high proportion of ties where some types of personal or social identification with the other actors motivates or influences economic actions (Granovetter, 1982; Hite, 2005). In the context of developing ideas into a real business plan, early networks are often associated with the accumulation of strong ties characterised by trust, support, and willingness to offer encouragement and support. These ties are more likely to provide confirmation on specific tacit ideas when other ties are 
unwilling to do so. Used as a means of opportunity exploration, the structure of entrepreneurs' networks at this stage were more restricted and dense where network contacts were probably known to each other.

Moving to the next stage (initial resource gathering stage), the entrepreneurs' networks did not radically transform into a new form of network. In fact, they still maintained close and strong ties but added some new contacts. Looking on the network density, the data shows that the entrepreneurs still relied on a high-density network where most of the contacts are connected. The purpose of networks in this stage is to help entrepreneurs confirm their ideas and make the decision to start their business. More importantly, entrepreneurs gathers their initial resources such as first investment, access to research facilities and information about market through their networks. The main networking activities can be described as an iterative process of gathering resources, reducing uncertainty, obtaining information, and acquiring confidence. The interaction is often based on mutual identification, a sense of social obligation, and enforceable trust (Portes \& Sensebrenner, 1993). Our data shows that the entrepreneurs had not strategically developed their networks; most confessed they had no strategic plan in building relationships. Formal structures were non-existent, with much of the activity focused on technical issues and early resource gathering. However, as the ideas started to turn into a reliable business plan, the entrepreneurs began developing networks with different stakeholders in the business. In some cases, these contacts were known to them, but had lain dormant until reactivation in response to their needs. "I called my former supervisor. I had barely seen him for years. But he knows the technology and I know that he was doing intensive research. I saw his name on the news. If you want to know the trend, he is the one you should talk to" (Ron - interview 027)

Fig. 2 below illustrates Tom's early network. There was a minor change in his network as he progressed into the resource gathering stage. Initially, his network was dominated by strong ties where most of the contacts knew each other confirming the formation of networks with high density. However, Tom had added two new contacts as he progressed to formally setting up the business: "I included them in this drawing as they were a basis of my business. He helped me with the business plan, he also referred me to the industry and helped me with the technology" (Tom-interview 04). Moreover, Tom's network was still characterised by strong ties including family and friends. Apparently, these network characteristics provided the basis to building confidence, trust, and the decision to start the new venture. 


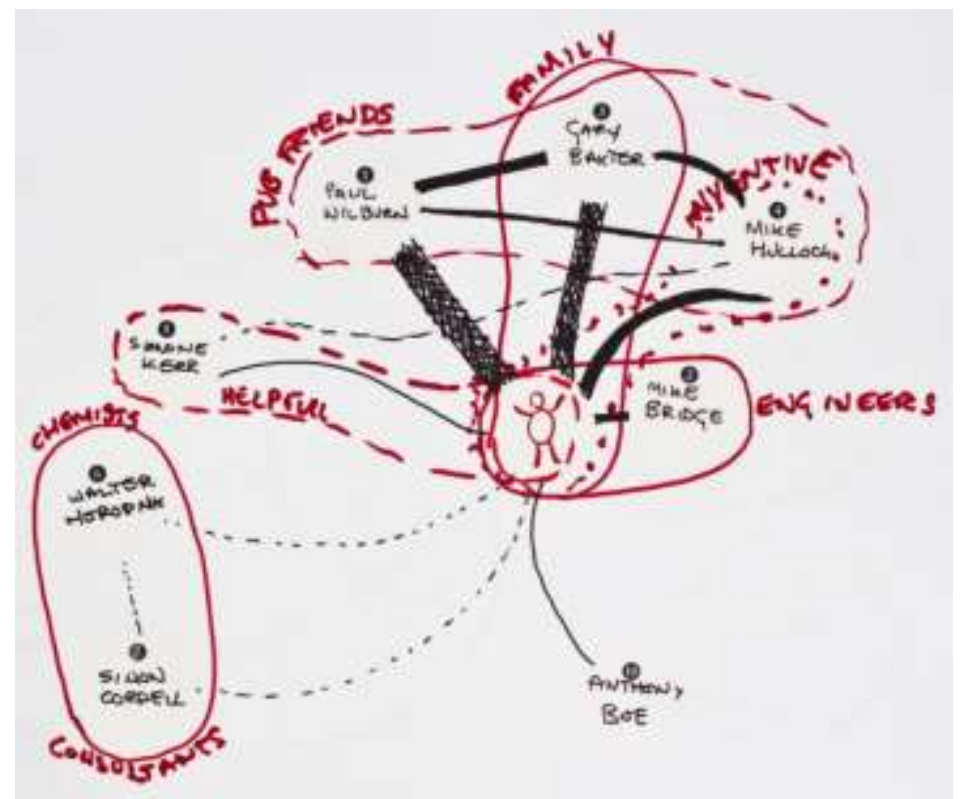

Fig. 2. Tom's network was dominated by family and friends.

\subsubsection{The second change in entrepreneurial networks: The creation of support-based networks}

The next network change episode occurred when the entrepreneurs had made the decision to exploit the opportunity and started to establish the new venture (Sullivan \& Ford, 2014). Having gained some resources and demonstrated market potential and technical feasibility, the entrepreneurs then went through an incubation stage where the main focus was on realising the commercial value of the product itself. An organisational structure and function began to emerge, albeit still in an embryonic state. In this stage, the entrepreneurs' main activity was to acquire and organise start-up activities, including finance, production, marketing, management, and the distribution channel. During this process, they faced some major challenges, such as acquiring physical facilities, establishing a network of reliable suppliers, developing product support, and approaching potential customers. The entrepreneurs also started to use networks as a source of learning to deal with managerial tasks, marketing, and regulations. Networking in this stage was rather dynamic, characterised by the increase of new and weak ties offering new information, knowledge, and access to resources that were not currently available to the entrepreneurs. Thus, when compared to the previous network characteristics, the networks in this stage consisted of a large number of new contacts including consultants, potential customers, suppliers, investors, incubator managers, and friends who intended to support the development of the new venture. In this network, the connection among network partners was rather loose, but motivated by supporting the entrepreneur in starting the business. The data suggested that the level of network density decreased significantly. Moreover, we found that few of the entrepreneurs' networks became stronger as some of their weak ties evolved into strong ties. However, the networks differed compared to the initial strong ties in the first stage. The strong ties developed at this stage had an economic motive as a part of the continuous development from the previous stage, as well as a social motive of trust and commitment. 
From the data, we found that this type of ties is relatively low as the overall network are dominated with weak ties and characterised as a low-density network. Apparently, the entrepreneurs developed a dynamic network that allowed them to gain market benefits.

To illustrate the creation of a support network, Fig. 3 shows Jon's network. Jon had a fairly large network. As most of the contacts were relatively new, the network was comparatively open with many weak ties. Talking about the reason for contacting the new network partners, he told us that the content of conversations was: “... about anything ... such as marketing, we talked about product specification, improvement, contracts... and also about how to find a business partner and potential collaborations", (Jon-interview 084). Moreover, another quote from the interview shows that John benefited from his new contacts. After securing a grant from a government research fund, Jon decided to develop his first product. This connection was facilitated by his new tie, the incubator's manager: "I got a lot of endorsement from Mr. Y (the incubator's manager). Access to funding was one of them, and he also provided me with access to experts in IP, government standards and regulations" (Jon-interview 126).

Our finding also confirms a relatively balanced number of old and new contacts at this stage, lending credence to the emergence of networks consisting of contacts with specialised skills, knowledge, and access to different resources. The reason for changing their network was due to the need to gain resources to exploit opportunities. In this stage, as Williamson (1993) pointed out, the entrepreneurs' motives become clear, and the networks mainly provided support, with greater focus on exploiting opportunities.

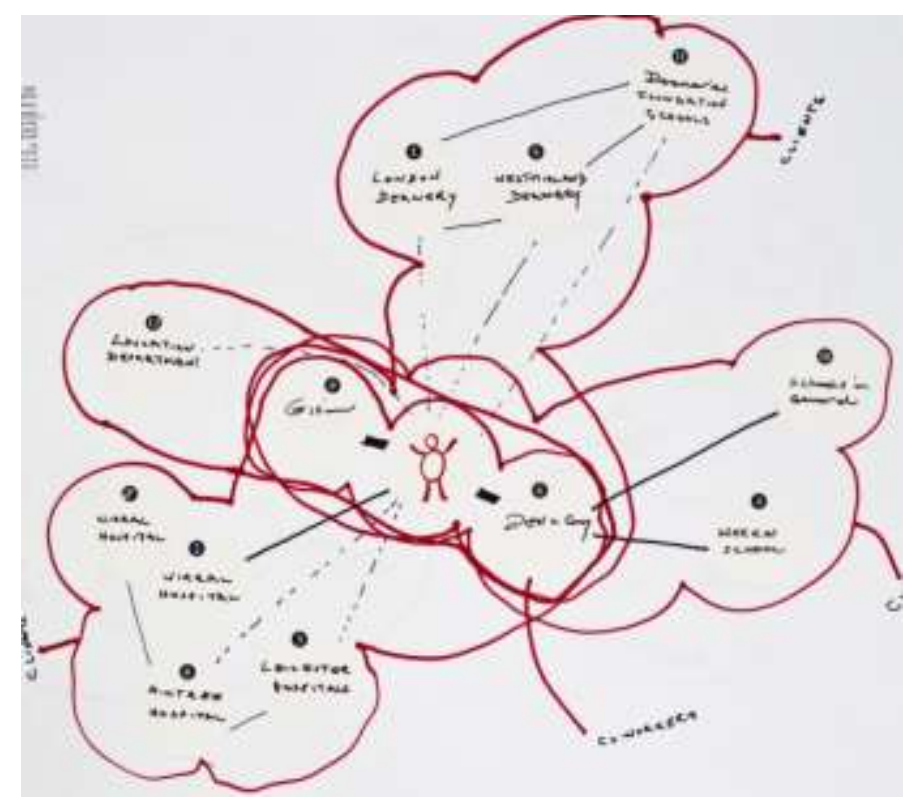

Fig. 3. Jon's network. 


\subsubsection{The third change in entrepreneurial networks: The creation of market-based networks}

The next network change episode occurred when the entrepreneurs used their networks to reconfigure resources to assemble the capabilities that enabled the firm to enter a market. As a result, more endeavour and resources were invested in coordinating the effort of each particular business unit. This meant a more formal network structure with suppliers or buyers. Using network mapping, the finding revealed that most entrepreneurs had divided their networks into several clusters. The clusters were mainly formed based on the role the network contacts played in relation to the entrepreneurs' business and access to resources. The clusters may not be well connected, but serve their own purpose. As a result, network clustering created a number of structural holes among the entrepreneurs' networks. The findings show that the level of network density was relatively low while the strength of ties decreased even further. It may be case that the entrepreneurs found new contacts related to market.

The figure below illustrates how the entrepreneur's networks were formed into clusters. For instance, one of the entrepreneurs, Ted, maintained a strong tie with the university supporting him with new developments while at the same time developing a strong network with business support organisations (consultants and government funding agencies) and customers. It seems the network became refined to accommodate the different challenges the entrepreneurs faced in this stage. Explaining the network and the change, Ted stated: "I had a strong position when I got the contract. It was proof that I had gained trust and reputation in the industry. I decided to hire more employees and considered my business network more seriously. I became aware that I needed to be more strategic in managing it" (Tedinterview 154). Looking on Ted's network, it is clear that his networks were dominated by many weak ties. Only limited number of ties were strong. It is also clear that contacts were not connected which result in the creation of low-density network.

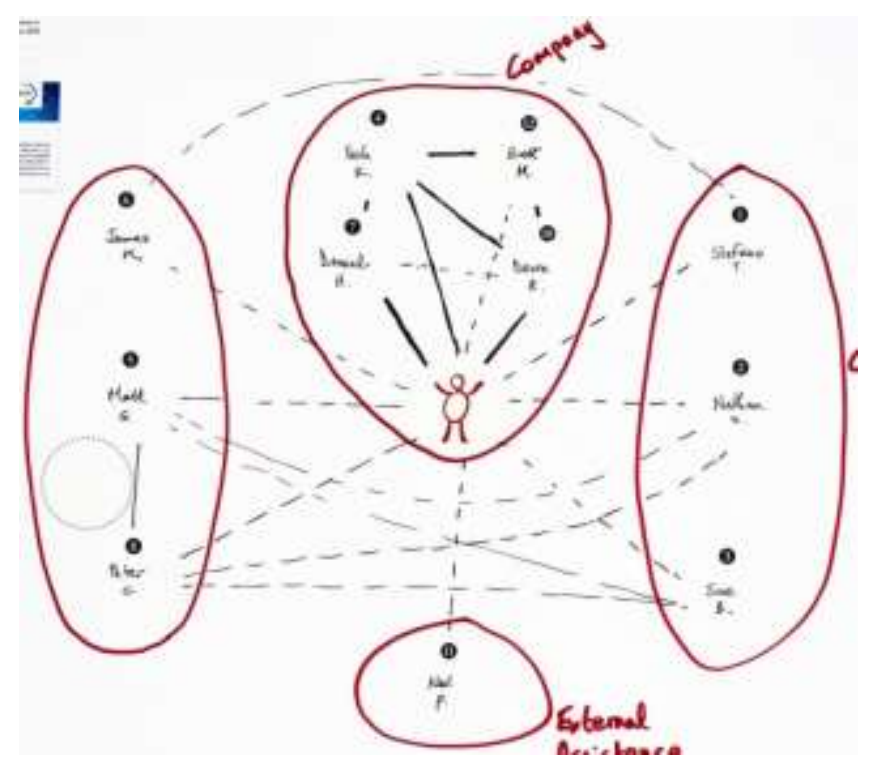

Fig. 4. Ted's network was clustered based on function. 


\subsubsection{The final change in entrepreneurial networks: The creation of core networks}

The last entrepreneurial network change took place when the entrepreneurs developed their core networks to sustain growth. During this process, the entrepreneurs realised that the most likely challenge could arise from existing networks. While the network contacts had helped them during the entrepreneurial stage, they may not be the most appropriate for a growth strategy, such as expanding to a new market or internationalisation. As one of the entrepreneurs stated: "The main reason for having this guy was our expansion strategy to penetrate a broader Eastern European market. We need to find solid partners who have experience with markets and are interested in our product. I met them through referral and he is now part of our team".

As the entrepreneurs moved through their lifecycle and started to grow, they needed to fine-tune their networks to accommodate future needs. As the purpose of the network at this stage was to ensure they were able to use the network for future growth, the entrepreneurs started to evaluate their existing networks. Facing a crisis and the lack of available contacts may force entrepreneurs to change their networks. Observing the structural and relational characteristics of networks, the entrepreneurs' networks consisted of relatively balanced strong and weak ties. However, the presence of structural holes was significant. As we found in the study, Fig. 5 confirms the presence of core networks for growth. In this stage, the exchange of relationships becomes more multiplex, with relationships starting initially for instrumental reasons imbued with a social or affective component. The network dyads commence as either social or affective relationships, or economic or instrumental ties. These onedimensional relationships transformed into socioeconomic exchanges through the actions and persuasive abilities of the entrepreneurs. The networks contained contacts that could effectively provide resources for growth and solutions to long-term business problems. Although the relationship between the entrepreneurs and their core contacts was relatively strong, the core contacts were not necessarily well connected. There is an element of trust and reliability in the entrepreneurs' networks where a balance between strong and weak ties provided benefits. As one entrepreneur mentioned: "I have a list of business friends, similar to the board of directors but not too formal, we usually meet every month or two. We discuss everything, from business to family. In my business, I introduced several new contacts, our business are connected and that why, we have trust here" (Mike, interview 170). 


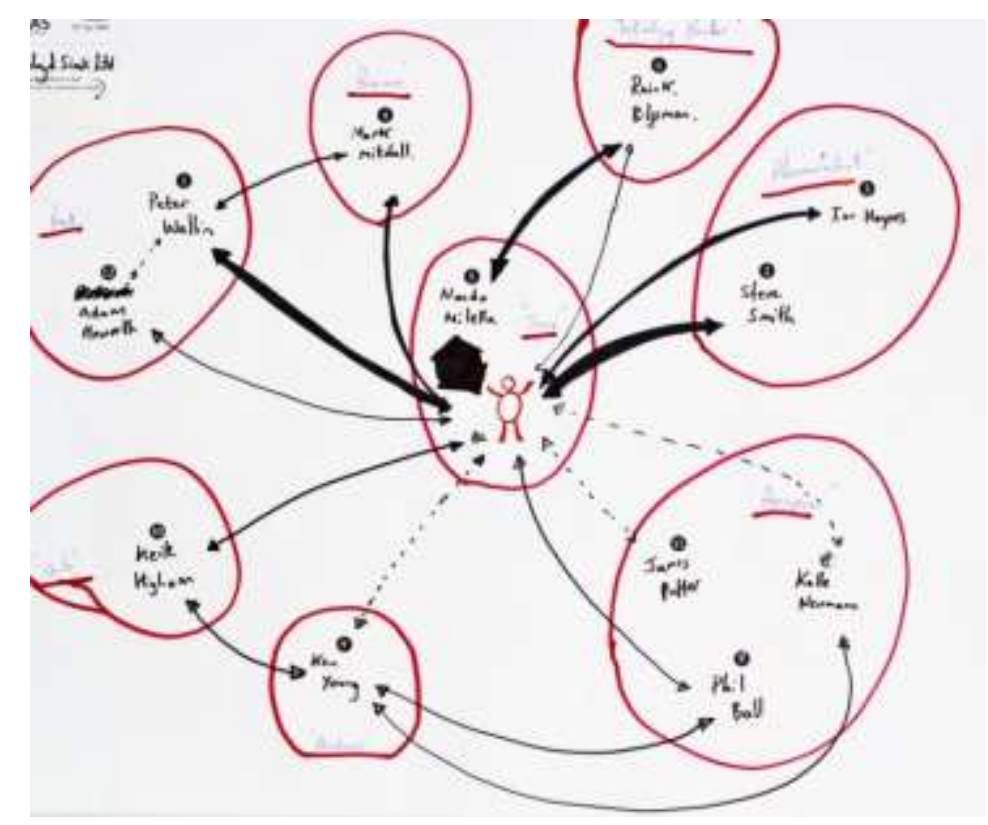

Fig. 5. Example of Mike's core network.

\section{Discussion}

By studying the development of networks over a period of 24 months, the findings reported here show that networks change in response to the challenges during new venture development. The study shows that networks constantly evolve in response to entrepreneurial needs at a specific development stage. We identify five development stages where networks are critical for entrepreneurs. These stages include opportunity exploration, resource gathering incubation, early market entry, and growth. In the early stage, entrepreneurs develop networks dominated by small number of contacts consisting friends, family and colleagues. These initial networks are characterised as high-density network with a high number of strong ties.

In the next stage, networks have evolved into support-based networks where strong ties decrease but weak ties increase. New contacts are introduced into the networks to bring new information, resources and knowledge that has not been available from the existing contacts. Those mixed contacts support entrepreneurs in activities such as developing product or service, seeking funding and investment, finding suppliers, acquiring entrepreneurial skills and dealing with intellectual property.

In the stage of early market entry, entrepreneurs start to change their network again. The study found that some of the weak ties turn into strong ties. These ties can be seen as a valuable addition to the existing networks especially where the existing ties are not able to solve the new challenges faced by the entrepreneurs. During this stage, we found that the entrepreneurs are relatively active in networking activities especially in making new connection with business players in the market. As a result, the entrepreneurs have developed market-based networks with structural holes where many of their contacts are not well-connected. Some of those contacts turn to be important for entrepreneurs especially in the final stage where the density of network increase as entrepreneurs develop their core networks. The 
networks are less dynamic and the size is relatively smaller compared to the networks from the previous stages.

Overall, the findings show that the entrepreneurs changed their networks during the entrepreneurial journey in response to their needs. The changing direction between strong ties and weak ties shows that entrepreneurs benefit from both types of ties. Similarly, both types of network density namely high and low-density network offer benefits for entrepreneurial activities. Overall, this study argues that the change in network is an evolution rather than a revolution. How the networks change is affected by the extent to which the entrepreneurs need to draw on their networks to fulfil their requirements. Fig. 6 summarises our findings.

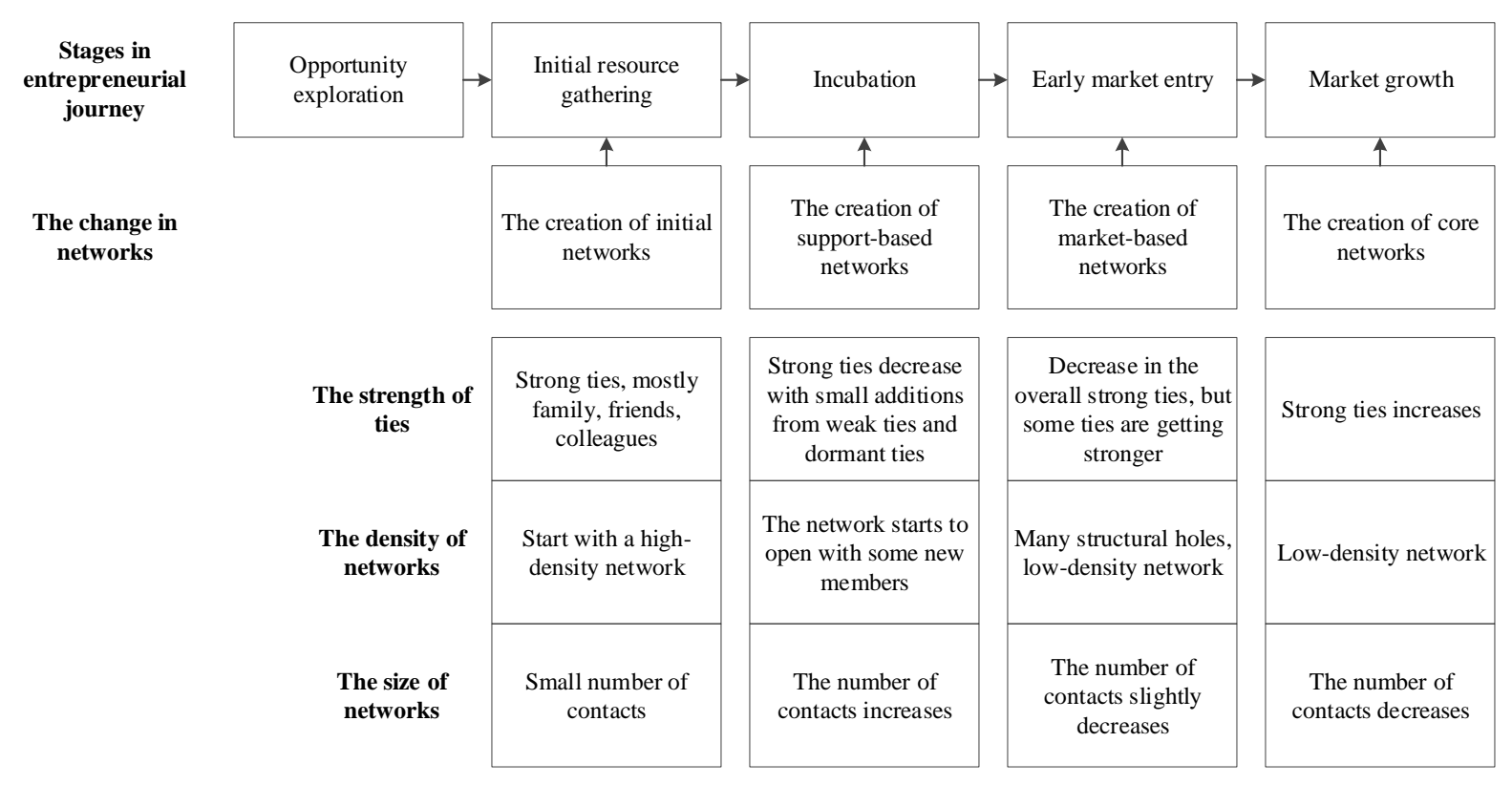

Fig. 6. Illustration of the study findings.

\section{Conclusion}

This paper has contributed to entrepreneurship literature by exploring the change in entrepreneurial networks using a network mapping approach. To meet our research objectives, we implement an innovative research design where entrepreneurs visually demonstrate how their networks have changed. Based on this network mapping approach, we find that entrepreneurial networks evolve dynamically in relation to entrepreneurial stages such as opportunity exploration, resource gathering, incubation, early market entry, and growth. Based on the characteristics of network, the change can be described as the initial networks change towards support-based networks, market-based networks, and the development of core networks. Given the nature of these findings, this study contributes to fostering understanding on network changes and the effectiveness of a network mapping approach as an alternative data collection methodology in network research. 
This study contributes to network literature in the several ways. First, it provides empirical evidence of how networks change. This work is a response to the calls of Gedajlovic et al. (2013), Jack (2010), Slotte-Kock and Coviello (2010), and von der Lippe and Gamper (2016) for more work around network change. While most extant studies observe networks by focusing only on a single dimension, our study considers both structural and relational network dimensions, showing how these differ in terms of development patterns. This result may extend recent works that lean on evolutionary network perspectives (Hite, 2005; Jack et al., 2008), bringing a more comprehensive understanding of how networks change. This study also raises interesting questions for those looking at networking activities in specific type of firms such as highly innovative firms or born-global firms, and identifying how networks are developed within such contexts. Second, our study examines how networks develop using a less traditional approach. By combining Hoang and Antoncic's (2003), Jack's (2010), Larson and Starr's (1993), and Slotte-Kock and Coviello's (2010) recommendations about future work with Nahapiet and Ghoshal's (1998) concept of network dimensions, this study develops network mapping as a tool for understanding network change. The interactive workshop and the network mapping successfully generated sufficient depth of data to explore network changes in response to entrepreneurial needs (Bürgi et al., 2005). Through discussions with respondents and engaging them in visualisation, it offers a way to capture detailed and rich information on their perceptions and understanding.

Despite the above contributions, our study has some limitations. First, there is always a potential memory problem in visualising networks, especially in exploring networks from the early stage. Although we put a great deal of effort into reducing the bias by giving considerable time for reflection, there is a possibility that respondents miss some details in their networks. Second, we have not accounted for the fact that entrepreneurs may develop their own entrepreneurial skills. In this case, entrepreneurs' new capability as a result of learning influences the strength of ties and the structure of networks. Third, while this research examines the needs during new venture development that determine the change in the entrepreneurial network, future research could consider other factors, such as entrepreneurs' networking style and networking support from incubator organisations. 


\section{References}

Aldrich, H., Rosen, B., \& Woodward, W. (1987). The impact of social network on business foundings and profit: A longitudinal study. In N.C. Churchill, J.A. Hornaday, B.A. Kirchhoff, O.J. Krasner and K.H. Vesper (Eds.), Frontiers of entrepreneurship research. Babson College, Wellesley, MA.

Ansoff, H. I. (1965). Corporate strategy: An analytic approach to business policy for growth and expansion. McGraw-Hill Companies, New York, NY.

Baum, J. A. C., Calabrese, T., \& Silverman, B. S. (2000). Don't go it alone: Alliance network composition and startups' performance in Canadian biotechnology. Strategic Management Journal, 21, 267-294.

Birley, S. (1985). The role of network in the entrepreneurial process. Journal of Business Venturing, 1(1), 107-117.

Bogdan, R., \& Biklen, S. (1982). Qualitative research for education: An introduction to theory and practice. Allyn and Bacon, Boston.

Borgatti, S. P., Jones, C., \& Everett, M. G. (1998). Network measures of social capital. Connections, 21(2), 27-36.

Brüderl, J., \& Preisendörfer, P. (1998). Network support and the success of newly founded businesses. Small Business Economics, 10, 213-225.

Bryman, A., \& Bell, E. (2003). Breaking down the quantitative/qualitative divide. Business Research Methods, 465-478.

Bürgi, P. T., Jacobs, C. D., \& Roos, J. (2005). From metaphor to practise: In the crafting of strategy. Journal of Management Inquiry, 14(1), 78-94.

Burt, R. (1992). Structural holes. Cambridge: Harvard University Press.

Burt, R. (2000). The network structure of social capital. In B.M. Staw and R. I. Sutton (Eds.), Research in organizational behaviour (pp. 345-423). JAI Press, Greenwich, CT.

Chell, Elizabeth (1998), "Critical Incident Technique," in Qualitative Methods and Analysis in Organizational Research: A Practical Guide, Gillian Symon and Catherine Cassell, eds. Thousand Oaks, CA: Sage, 51-72.

Coleman, J. S. (1990). Foundations of social theories. Harvard University Press, Cambridge.

Davidsson, P., \& Honig, B. (2003). The role of human and social capital among nascent entrepreneurs. Journal of Business Venturing, 18(3), 301-331.

Easterby-Smith, M., Thorpe, R., \& Lowe, A. (2002). Management research: An introduction. 2nd Edition. Sage Publications, London.

Engel, Y., Kaandorp, M., \& Elfring, T. (2017). Toward a dynamic process model of entrepreneurial networking under uncertainty. Journal of Business Venturing, 32(1), 35-51.

Eisenhardt, K. (1989). Building theories from case study research. Academy of Management Review, 14(4), 532-550.

Elfring, T., \& Hulsink, W. (2007). Networking by entrepreneurs: Patterns of tie formation in emerging organizations. Organization Studies, 28, 1849-1872.

Galunic, D. C., \& Eisenhardt, K. M. (2001). Architectural innovation and modular corporate forms. Academy of Management journal, 44(6), 1229-1249. 
Gedajlovic, E., Honig, B., Moore, C. B., Payne, G. T., \& Wright, M. (2013). Social capital and entrepreneurship: A schema and research agenda. Entrepreneurship Theory and Practice, 37(3), $455-478$.

Granovetter, M. (1982). The strength of weak ties: A network theory revisited. In P.V. Marsden and Nan Lin (Eds.), Social structure and network analysis. Sage, Beverly Hills.

Granovetter, M. (2005). The impact of social structure on economic outcomes. The Journal of Economic Perspectives, 19(1), 33-50.

Greve, A., \& Salaff, J. (2003). Social network and entrepreneurship. Entrepreneurship Theory and Practice, 28(1), 1-22.

Gummesson, E. (2000). Qualitative methods in management research. Thousand Oaks: Sage Publications, Beverly Hills.

Hansen, M. T. (1999). The search-transfer problem: The role of weak ties in sharing knowledge across organization subunits. Administrative science quarterly, 44(1), 82-111.

Hill, J., McGowan, P., \& Drummond, P. (1999). The development and application of a qualitative approach to researching the marketing network of small firm entrepreneurs. Qualitative Market Research, 2(2), 71-81.

Hite, J. (2005). Evolutionary processes and paths of relationally embedded network ties in emerging entrepreneurial firms. Entrepreneurship Theory and Practice, 29(1), 113-144.

Hite, J. (2008). The role of dyadic multi-dimensionality in the evolution of strategic network ties. In J.A.C. Baum and T.J. Rowley (Eds.), Network strategy (pp. 133-170). JAI Press: Bingley, UK.

Hite, J., \& Hesterly, W. (2001). The evolution of firm network: from emergence to early growth of the firm. Strategic Management Journal, 22, 275-286.

Hoang, H., \& Antoncic, B. (2003). Network based research in entrepreneurship: A critical review. Journal of Business Venturing, 18, 165-187.

Hoepfl, M. C. (1997). Choosing qualitative research: A primer for technology education researchers. Journal of Technology Education, 9(1), 1-16.

Huff, A. S. (1990). Mapping strategic thought. John Wiley \& Sons, Chichester, UK.

Huff, A. S., \& Jenkins, M. (Eds.). (2002). Mapping strategic knowledge. Sage, Thousand Oaks, CA.

Ibarra, H., Kilduff, M., \& Tsai, W. (2005). Zooming in and out: Connecting individuals and collectivities at the frontiers of organizational network research. Organization Science, 16(4), 359371.

Jack, S. L. (2005). The role, use and activation of strong and weak ties: A qualitative analysis. Journal of Management Studies, 42(6), 1233-1259.

Jack, S. L. (2010). Approaches to studying network: implications and outcomes. Journal of Business Venturing, 25(1), 120-137.

Jack, S. L., Dodd, S. D., \& Anderson, A. R. (2008). Change and the development of entrepreneurial network over time: A processual perspective. Entrepreneurship and Regional Development, 20(2), $125-159$.

Jack, S., Moult, S., Anderson, A. R., \& Dodd, S. (2010). An entrepreneurial network evolving: Patterns of change. International Small Business Journal, 28(4), 315-337. 
Johannisson, B. (1998). Personal network in emerging knowledge based firms: spatial and functional patterns. Entrepreneurship and Regional Development, 10(4), 297-312.

Jonsson, S. (2015). Entrepreneurs' network evolution - the relevance of cognitive social capital. International Journal of Entrepreneurial Behaviour and Research, 21(2), 197-223.

Koka, B. R., Madhavan, R., \& Prescott, J. E. (2006). The evolution of interfirm networks: Environmental effects on patterns of network change. Academy of Management Review, 31(3), 721737.

Krackhardt, D. (1995). Entrepreneurial opportunities in an entrepreneurial firm: a structural approach. Entrepreneurship: Theory and Practice, 19(3), 53-70.

Kreiser, P. M., Patel, P. C., \& Fiet, J. O. (2013). The Influence of Changes in Social Capital on FirmFounding Activities. Entrepreneurship Theory and Practice, 37(3), 539-568.

Larson, A. (1992). Network dyads in entrepreneurial settings: A study of the governance of exchange relationships. Administrative science quarterly, 76-104.

Larson, A., \& Starr, J. (1993). A network model of organization formation. Entrepreneurship Theory and Practice, 17(2), 5-15.

Leitch, C., Hill, F., \& Harrison, R. (2010). The philosophy and practice of interpretivist research in entrepreneurship: Quality, validation and trust. Organizational Research Methods, 13(1), 67-84.

Lechner, C., Dowling, M., \& Welpe, I. (2006). Firm networks and firm development: The role of the relational mix. Journal of business venturing, 21(4), 514-540

Lechner, C., \& Dowling, M. (2003). Firm networks: external relationships as sources for the growth and competitiveness of entrepreneurial firms. Entrepreneurship \& Regional Development, 15(1), 126.

MacAdam, M., \& Marlow, S. (2008). A preliminary investigation into networking activities within the university incubators. International Journal of Entrepreneurial Behaviour and Research, 14(4), 219-241.

Martinez, M. A., \& Aldrich, H. E. (2011). Networking strategies for entrepreneurs: Balancing cohesion and diversity. International Journal of Entrepreneurial Behaviour and Research, 17(1), 7-38.

McEvily, B., \& Zaheer, A. (1999). Bridging ties: A source of firm heterogeneity in competitive capabilities. Strategic Management Journal, 20, 1133-1156.

Mintzberg, H. (1987). Crafting strategy. Harvard Business Review, 65(5), 66-75.

Nahapiet, J., \& Ghoshal, S. (1998). Social capital, intellectual capital and the organizational advantage. Academy of Management Review, 23(2), 242-266.

Newbert, S. L., Tornikoski, E. T., \& Quigley, N. R. (2013). Exploring the evolution of supporter networks in the creation of new organizations. Journal of Business Venturing, 28(2), 281-298

Parkhe, A., Wasserman, S., \& Ralston, D.A. (2006). New frontiers in network theory development. Academy Management Review, 31(3), 560-568.

Patton, M. Q. (1990). Qualitative evaluation and research methods (2nd ed.). Newbury Park, CA: Sage Publications Inc.

Piaget, J. (1971). Genetic epistemology, Norton Library, New York. 
Podolny, J. M., \& Baron, J. N. (1997). Resource and relationships: Social network and the mobility in the workplace. American Sociological Review, 62, 673-693.

Porter, M. E. (1980). Competitive strategy: Techniques for analyzing industry and competitors, Free Press: New York.

Portes, A., \& Sensenbrenner, J. (1993). Embeddedness and immigration: Notes on the social determinants of economic action. American journal of sociology, 98(6), 1320-1350.

Schutjens, V., \& Stam, E. (2003). The evolution and nature of young firm networks: A longitudinal perspective. Small Business Economics, 21( 2), 115-134.

Slotte-Kock, S., \& Coviello, N. (2010). Entrepreneurship research on network processes: A review and ways forward. Entrepreneurship Theory and Practice, 34(1), 31-57.

Sullivan, D. M., \& Ford, C. M. (2014). How entrepreneurs use networks to address changing resource requirements during early venture development. Entrepreneurship Theory and Practice, 38(3), 551574.

Von der Lippe, H., \& Gamper, M. (2016). Drawing or tabulating ego-centered networks? A mixedmethods comparison of questionnaire vs. visualization-based data collection. International Journal of Social Research Methodology, 20(5), 425-441.

Williamson, O. E. (1993). Calculativeness, trust, and economic organization. The Journal of Law and Economics, 36(1, Part 2), 453-486.

Zaheer, A., \& Bell, G. G. (2005). Benefiting from network position: Firm capabilities, structural holes, and performance. Strategic Management Journal, 26, 809-825. 


\section{APPENDIX}

The sample consist of firms/entrepreneurs from different stages in their business. Over the duration of 24 months, the study followed their progress while were observing the change of the networks of 15 entrepreneurs.

The data collection (the sequence of the visit and the samples)

\begin{tabular}{|l|l|}
\hline $\begin{array}{l}\text { Data collection (visit for } \\
\text { individual case) }\end{array}$ & Stage and the sample coding* \\
\hline $1^{\text {st }}$ & $\begin{array}{l}\text { Opportunity exploration: } 1,2,3,6,7,8 \\
\text { Resource gathering: 4,10,11,12 } \\
\text { Incubation: } 5,9,13,14,15\end{array}$ \\
\hline $2^{\text {nd }}$ & $\begin{array}{l}\text { Opportunity exploration: } 2,3,8 \\
\text { Resource gathering: } 1,4,6,7,10 \\
\text { Incubation: } 5,11,12,13,14 \\
\text { Early market entry: } 9,15\end{array}$ \\
\hline $3^{\text {rd }}$ & $\begin{array}{l}\text { Resource gathering: } 2,3,8 \\
\text { Incubation: } 1,4,6,7 \\
\text { Early market entry: } 5,10,11,12,13,14,15 \\
\text { Market growth: } 9\end{array}$ \\
\hline $4^{\text {th }}$ & $\begin{array}{l}\text { Incubation: } 2,3,8 \\
\text { Early market entry: } 1,5,6,7,13 \\
\text { Market growth: } 9,11,12,14,15\end{array}$ \\
\hline $5^{\text {th }}$ & $\begin{array}{l}\text { Incubation: } 8 \\
\text { Early market entry: } 2,3,5 \\
\text { Market growth:1,6,7,9,10,11,12,13,14,15 }\end{array}$ \\
\hline
\end{tabular}

